\title{
DISTILLATION CLEANUP PRECEDED GC DETERMINATION OF SHORT-CHAIN MONOCARBOXYLIC ACIDS IN AQUEOUS AND SOLID SAMPLES OF WASTEWATER ORIGIN
}

\author{
OZNACZANIE KRÓTKOłAŃCUCHOWYCH KWASÓW \\ MONOKARBOKSYLOWYCH W PRÓBKACH WODNYCH I STAŁYCH \\ POCHODZĄCYCH Z OCZYSZCZALNI ŚCIEKÓW Z WYKORZYSTANIEM \\ CHROMATOGRAFII GAZOWEJ POPRZEDZONEJ DESTYLACJĄ
}

\begin{abstract}
Short-chain monocarboxylic acids (SCMAs) (C2-C5) formed in the process of aerobic biodegradation of larger organic molecules should often be monitored to optimize wastewater biological treatment and study the processes of converting organic waste matter into methane, etc. Gas chromatography (GC) seems a method of choice for such a task. Majority of samples require clean up before they can be injected into GC system. In this work a special refluxing apparatus is applied to concentrate and clean up the troublesome environment samples before injection into GC. To optimize separation of SCMAs in aqueous sample a special arrangement of two capillary columns, of very different polarity was used. The operational parameters of sample preparation were optimized and enrichment factors determined. The procedure developed was applied to determine SCMAs in troublesome aqueous and solid samples of wastewater treatment origin.
\end{abstract}

Keywords: short-chain monocarboxylic acids, distillation, gas chromatography-flame ionization detector, wastewater

Short-chain monocarboxylic acids (SCMAs) are compounds containing from 2 to 5 carbon atoms in a molecule and are present in various environmental elements. Furthermore, they are, in fact, always present in wastewater containing organic matter due to microbial activity and play an important role in biological wastewater treatment. In process of biological treatment they are a source of carbon, which can be easily assimilated by Acinetobacter, which has a significant impact on the removal of phosphorous from the effluent. The content of SCMAs in wastewater at successive treatment steps should be known when designing and operating the plant. By measuring and controlling SCMAs content the process of phosphorous removal can be analyzed and initial sewage sludge fermentation can be controlled [1,2]. The determination of SCMAs in raw and treated wastewater, waste site leachates, surface and groundwater is a tool to evaluate the state of

\footnotetext{
${ }^{1}$ Department of Analytical Chemistry, Chemical Faculty, Gdansk University of Technology (GUT), ul. G. Narutowicza 11/12, 80-233 Gdańsk, Poland, phone +48 5834721 10, fax +48 583472694

*Corresponding author: anik.jakimus@interia.pl
} 
the environment and effect of treatment plants on the quality of environment. The total SCMAs content is often determined by titration of wastewater distillates [3-5] or often original samples. High detection limits $\left(>36 \mathrm{mg} \mathrm{dm}^{-3}\right)$ and the fact that each acid can have different effect on treatment processes and on water quality deterioration have been the reasons to develop analytical methods of individual acids determination [6]. Gas chromatography is a method of choice for such an analytical task. Always the simplest approach is to introduce the original sample to the instrument, in this case into a gas chromatograph. However, this can be employed only if an aqueous sample is sufficiently clean and separation and detection systems are compatible with water and concentration is above the detection limit. Critical is the selection of the separation system.

Polyethylene glycol (PEG) [7-11], generally treated with nitroterephthalic acid [1, 12-15] to deactivate alkaline sites, is most often used as a stationary phase for separation of short-chain fatty acids. Other polar stationary phases were also applied to analyse water samples; for example polybiscyanopropyl (90\%) - cyanopropylphenylsiloxane (10\%) stationary phase to determine acids extracted from plants [16]. Zygmunt and Banel [17] obtained good separation of acids with 2-4 carbon atoms in a molecule using a polycyanopropyl $(6 \%)$ - dimethyl $(94 \%)$ polysiloxane stationary phase. When converted to derivatives, SCMAs can be separated on a wider spectrum of capillary columns. For instance, Pan and Pawliszyn [18, 19] used a capillary column coated with polydimethylsiloxane (95\%) - diphenylsiloxane (5\%) and achieved good results for free fatty acids and their derivatives obtained by treatment with pyrenyldiazomethane (PDAM), 1-pafluorphenyldiazoethane (PFPDE) or pentafluorbenzyl bromide (PFBB).

Especially useful for separation of polar compounds in aqueous samples are solid organic polymers such as polydivinylbenzene (DVB), immobilized on a column wall. This PLOT column provides good selectivity and is thermally stable and resistant to many chemicals. The application of slightly polar as well as non-polar stationary phases in the determination of SCMAs in water causes some problems. A column coated with trifluorpropylpolysiloxane was used for the separation of short-chain fatty acids in an aqueous distillery effluent. Good quantitative results due to application of special statistical data treatment were achieved [20]. The obstacles to apply the approach are: low concentration and complexity of a matrix which make it necessary to include an enrichment and isolation step in the analythical procedure [20].

Many isolation and enrichment techniques have been applied to solve the problem. Distillation based determination of SCMAs has appeared to have low thermal degradation potential [21]. Another variety is nitrogen purge and steam distillation (NPSD) [22], which, in general, is applied in the case of samples with a very complex matrices. The combination of simple and steam distillation, and also nitrogen purge and steam distillation (NPSD) [22] were applied for very complex samples.

The distillate is sufficiently clean to be injected directly into GC for determination of individual acids. To improve the quality of the results a special variety of distillation was applied.

The aim of this study was to develop a method of SCMAs determination in aqueous and possibly solid samples with very complex matrices using distillation based sample clean-up and GC with in-series connected columns to separate SCMAs. 


\section{Experimental}

\section{Chemicals and solutions}

C2-C5 monocarboxylic acids were purchased from Fluka (Switzerland), methanol was from Merck (Germany) and 95\% sulphuric acid was from POCh (Poland). High purity water was acquired by using a Millipore QPLUS 185. Standard aqueous samples were made by spiking organic free water with the standard solution of SCMAs in methanol; the solution was prepared by dissolving weighed amounts of analytes in methanol. 2-ethylbutanoic acid was a surrogated standard and was added to samples before analysis to correct for possible differences in injection volumes.

\section{Real samples}

Aqueous samples. Municipal wastewater was sampled into $0.5 \mathrm{dm}^{3}$ high-density-polyethylene (HDPE) bottles (Kautex) at wastewater treatment plant; it was wastewater leaving grating and treated wastewater discharged to a receiver.

Before use the bottles were carefully cleaned up, rinsed with reverse osmosis purified water (MilliQ A10 Gradient/Elix System, Millipore; Bedford, MA, USA) and then twice with the sampled medium. The bottles were filled up to the brim, transported to the lab in ice-cooled boxes (within $4 \mathrm{~h}$ ), and then acidified and stored at $4^{\circ} \mathrm{C}$.

Solid samples. The real solid samples analyzed were digested sewage sludge and compost, which were collected from deep layers, because SCMAs compounds could have evaporated from surface layer due to their high volatility. All samples were collected into $0.5 \mathrm{dm}^{3}$ HDPE bottles with a shovel. Samples were transported and stored in the same way as water samples.

\section{Distillation}

Standard and real samples were subjected to a sort of fractional distillation using a custom made apparatus similar to that proposed by Peters [23].

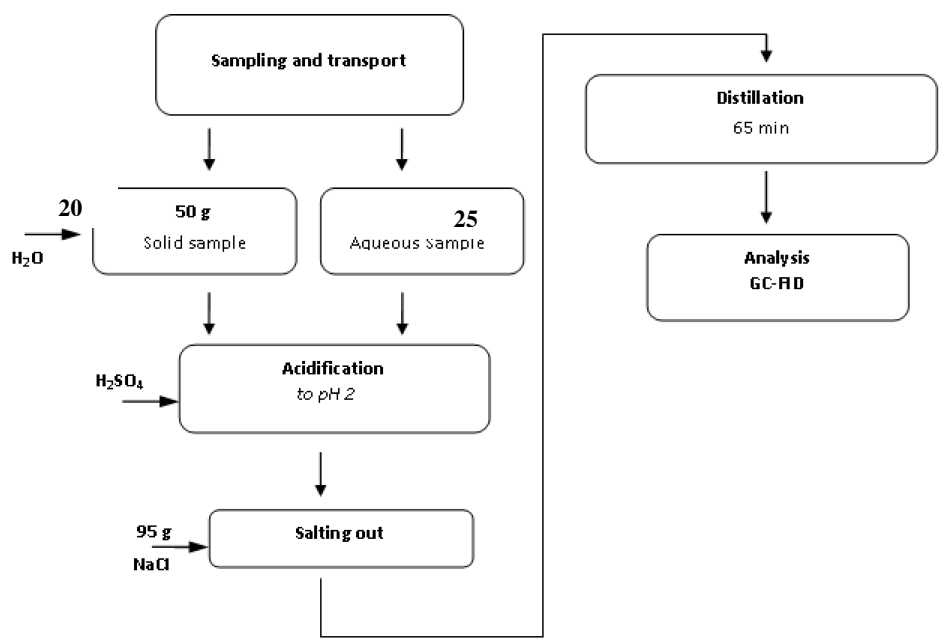

Fig. 1. Schematic diagram of the developed analytical procedure of determination of SCMAs 
The apparatus is composed of a $1 \mathrm{dm}^{3}$ distillation flask placed in a heating mantle, a short rectifying column and a reflux condenser with a small volume chamber where the condensate collects. When the chamber is filled up, the condensate overflows and the chamber is refilled with a fresh distillate. The condensate can be sampled during distillation process with a microsyringe by piercing a syringe needle through a septum closing the chamber.

A $250 \mathrm{~cm}^{3}$ standard or real aqueous sample was poured out into a $1 \mathrm{dm}^{3}$ round-bottom flask, acidified to $\mathrm{pH} 2$ with sulphuric acid, salted out by adding $95 \mathrm{~g} \mathrm{NaCl}$ and then an internal standard in methanol was introduced. The content was refluxed for $65 \mathrm{~min}$ and then $2 \mathrm{~mm}^{3}$ distillate aliquots were taken from the chamber and injected to a GC injection port for analysis. The concentrations were calculated by comparing the sample chromatogram with the chromatogram of standard solution processed in the same way. The final analytical procedure is schematically presented in Figure 1.

\section{GC-FID instrumentation and analysis}

A GC Carlo Erba Instruments gas chromatograph equipped with a split/splitless injector and a flame ionization detector (FID) was used to separate and quantify SCMAs. The following combination of chromatographic columns was used: SUPEROX FA II (Bio-Rad)/polyethylene glycol/(10 m x $0.53 \mathrm{~mm} \times 1.20 \mu \mathrm{m})$, deactivated capillary ( $2 \mathrm{~m} \times 0.53 \mathrm{~mm})$, Restek Rtx-1/dimethyl polysiloxane $/(30 \mathrm{~m} \times 0.53 \mathrm{~mm} \times 5 \mu \mathrm{m})$ and guard column $(0.5 \mathrm{~m} \mathrm{x} 0.32 \mathrm{~mm})$ [24]. Temperature program was $80^{\circ} \mathrm{C}(30 \mathrm{~s})$ then $7^{\circ} \mathrm{C} / \mathrm{min}$ to $220^{\circ} \mathrm{C}(2 \mathrm{~min})$. Hydrogen (Air Products, Poland) at a flow-rate of $22.0 \mathrm{~cm}^{3} \mathrm{~min}^{-1}$ was a carrier gas. Air was from Oxygen s.c., Gdansk, Poland. The injection port and detector were set at $250^{\circ} \mathrm{C}$. Injection volume was $2 \mathrm{~mm}^{3}$ [24].

\section{Results and discussion}

\section{Selection of distillation parameters}

Developing an analytical procedure for SCMAs in aqueous samples included optimization quite a few parameters mainly those connected with sample preparation.

\section{Time and sample volume}

The time of distillation should be the shortest time after which the area of peaks of interest no more increases. To select this parameter, a concentrate was sampled from the concentrate chamber and subjected to GC analysis. When no further increase, within an experimental error, in peak areas was observed it was assumed that steady state was achieved. That time was found to be similar for all the studied acids and no longer than 60 min for majority of analyte acids and sample volumes in the range of $250 \div 750 \mathrm{~cm}^{3}$. However, the highest constant analyte concentration in the condensate was found for $95 \mathrm{~min}$ at a sample volume of $250 \mathrm{~cm}^{3}$.

\section{Salt addition}

Salt addition (sodium chloride) studied in the amount from 0 to $95 \mathrm{~g}$ to $250 \mathrm{~cm}^{3}$ of the aqueous solution had a positive effect on SCMA content in the condensate (Fig. 2). 


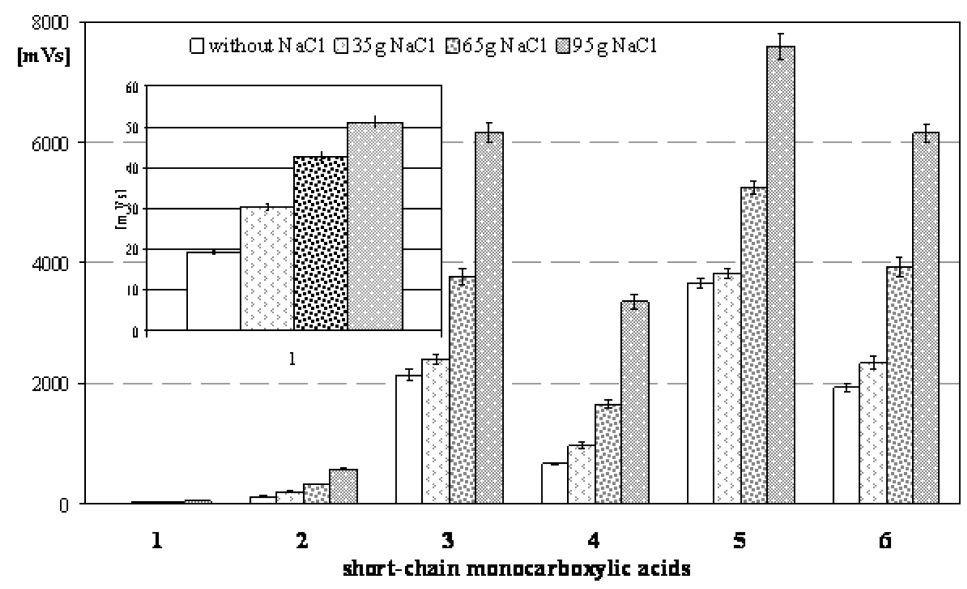

Fig. 2. The effect of salt addition on SCMAs concentration (peak areas) in a condensate (sample volume $250 \mathrm{~cm}^{3}$ ) [1 - ethanoic acid, 2 - propanoic acid, $\mathbf{3}$ - 2-methylopropanoic acid, 4 - butanoic acid, 5 - 3-methylbutanoic acid, 6 - pentanoic acid]

At $95 \mathrm{~g} \mathrm{NaCl}$ per $250 \mathrm{~cm}^{3}$ aqueous SCMAs solution the increase in an enrichment factor (EF) defined as a ratio of the concentration of a given acid in a condensate to its concentration in a sample, ranged from 2.1 fold for 3-methylbutanoic acid and to 5.0 fold for butanoic acid.

Salt addition also decreased the time of reaching steady state from 95 to $65 \mathrm{~min}$ (Fig. 3).

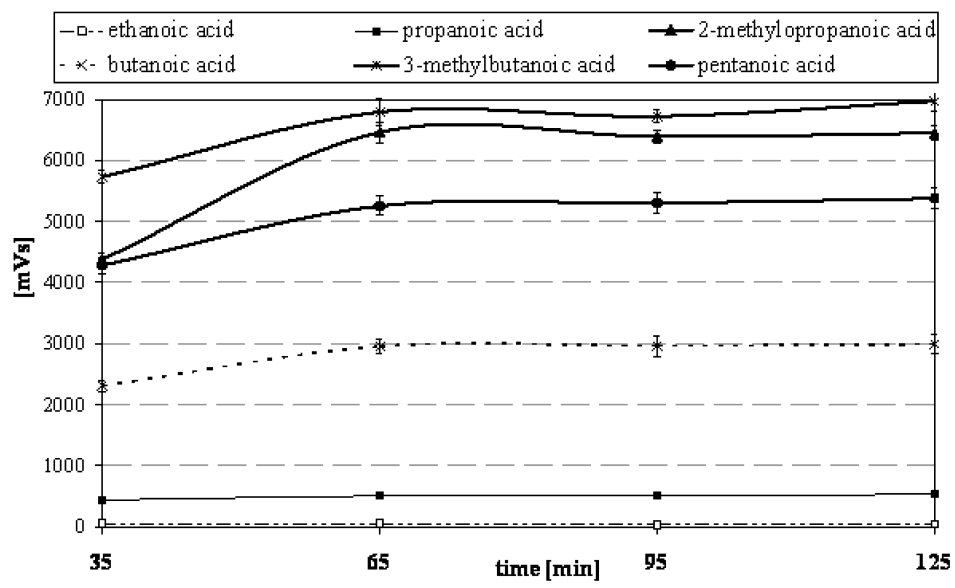

Fig. 3. The effect of distillation time on concentration (peak areas) in a condensate in the presence of $\mathrm{NaCl}\left(95 \mathrm{~g}\right.$ per $\left.250 \mathrm{~cm}^{3}\right)$

For the fixed distillation conditions approximate enrichment factors of SCMAs in the presence and absence of salt are given in Table 1. With no salt presence the enrichment 
factor for ethanoic acid was below 1 (dilution not enrichment) while it was above 1.0 (enrichment) at a salt concentration of $380 \mathrm{~g} \mathrm{dm}^{-3}$. Also repeatability of the results was better - coefficients of variation (CV) were not exceeding $8 \%$.

The enrichment factors (EF) of SCMAs in the presence and absence of $\mathrm{NaCl}$

Table 1

\begin{tabular}{|c|c|c|c|c|}
\hline \multirow{2}{*}{ SCMAs } & \multicolumn{2}{|c|}{ Without NaCl } & \multicolumn{2}{c|}{ Added 95 g NaCl } \\
\cline { 2 - 5 } & $\mathrm{EF} \pm \mathrm{S}^{*}$ & $\mathrm{CV}[\%]$ & $\mathrm{EF} \pm \mathrm{S}^{*}$ & $\mathrm{CV}[\%]$ \\
\hline Ethanoic acid & $0.321 \pm 0.029$ & 7.87 & $5.63 \pm 0.22$ & 3.44 \\
\hline Propanoic acid & $1.402 \pm 0.035$ & 2.18 & $8.92 \pm 0.81$ & 7.88 \\
\hline 2-methylpropanoic acid & $18.1 \pm 1.6$ & 7.71 & $27.0 \pm 2.0$ & 6.41 \\
\hline Butanoic acid & $5.85 \pm 0.29$ & 4.30 & $17.03 \pm 0.80$ & 4.10 \\
\hline 3-methylbutanoic acid & $21.0 \pm 2.0$ & 7.98 & $17.4 \pm 1.4$ & 7.43 \\
\hline Pentanoic acid & $13.1 \pm 1.3$ & 8.31 & $18.42 \pm 0.21$ & 1.01 \\
\hline
\end{tabular}

*S - standard deviation

\section{Determination of validation parameters}

\section{Linearity and precision}

Quantitative interpretation of chromatograms of real samples was based on a method of external standard. Standard working solutions of SCMAs ranging in concentration from 0.1 to $50 \mathrm{mg} \mathrm{dm}^{-3}$ were prepared by spiking organic free water with the standard solutions of SCMAs in methanol at concentrations of 75000 and $5000 \mathrm{mg} \mathrm{dm}^{-3}$. 2-ethylbutanoic acid was added to working solutions and samples in order to correct for the differences in the injected volumes.

The linear regression was used to describe the response-concentration dependence. The best fittings were observed when the concentration range was divided into two segments depending on the acid; first for the concentrations close to LODs. The regression coefficients were never lower than 0.9843 and the coefficients of variation $(\mathrm{CV})$ were below $9 \%$.

\section{Limits of detection and quantitation}

Taking into account enrichment factors presented in Table 1, the detection limits of whole analytical process could have been assessed (Table 2).

The detection and quantitation limits of GC-FID procedure of SCMAs determination proceeded by distillation based isolation and enrichment

\begin{tabular}{|c|c|c|}
\hline \multirow{2}{*}{ SCMAs } & LOD & LOQ \\
\cline { 2 - 3 } & \multicolumn{2}{|c|}{$\left[\mathrm{g} \mathrm{dm}^{-3}\right]$} \\
\hline Ethanoic acid & 3.4 & 10 \\
\hline Propanoic acid & 1.9 & 5.7 \\
\hline 2-methylpropanoic acid & 0.59 & 1.8 \\
\hline Butanoic acid & 1.5 & 4.6 \\
\hline 3-methylbutanoic acid & 3.6 & 11 \\
\hline Pentanoic acid & 3.9 & 12 \\
\hline
\end{tabular}


Detection limits were calculated from calibration functions [25] using equation:

$$
L O D=3.3 \cdot S / b
$$

where $S$ is the residual standard deviation of calibration function and $b$ is the slope of the corresponding linear function.

The quantitation limits (LOQ) defined as 3 LOD were acid dependent and ranged from 1.8 to $12 \mu \mathrm{g} \mathrm{dm}^{-3}$ for aqueous standard samples.

\section{Real samples}

The procedure developed was applied to determine SCMAs in samples with a very complex matrix such as compost pile leachate, municipal wastewater, sewage sludge and compost. The concentration of free short-chain monocarboxylic acids in aqueous samples of raw sewage ranged from $4.0 \mathrm{mg} \mathrm{dm}^{-3}$ (pentanoic acid) to $96 \mathrm{mg} \mathrm{dm}^{-3}$ (ethanoic acid), whereas in samples of treated wastewater were below LOQ. In samples of leachate, concentrations of SCMAs ranged from $1.26 \mathrm{mg} \mathrm{dm}^{-3}$ (3-methylbutanoic acid) to $668 \mathrm{mg} \mathrm{dm}^{-3}$ (ethanoic acid).

Within the studies the applicability of this procedure was also examined for the determination of SCMAs in solid samples, eg compost piles and sewage sludge, by mixing them with water and subjected the mixture to distillation process. As seen from Figure 4 the fresh compost pile contains many volatile organic compounds including SCMAs. Sewage sludge was relatively poor in SCMAs - concentrations ranged from $1.37 \mathrm{mg} \mathrm{\textrm {dm } ^ { - 3 }}$ (3-methylbutanoic acid) to $28.5 \mathrm{mg} \mathrm{dm}^{-3}$ (ethanoic acid) and $5.27 \mathrm{mg} \mathrm{dm}^{-3}$ (pentanoic acid) to $847 \mathrm{mg} \mathrm{dm}^{-3}$ (ethanoic acid) for compost pile and sewage sludge, respectively. In all the samples, ethanoic and propanoic acids were dominant.

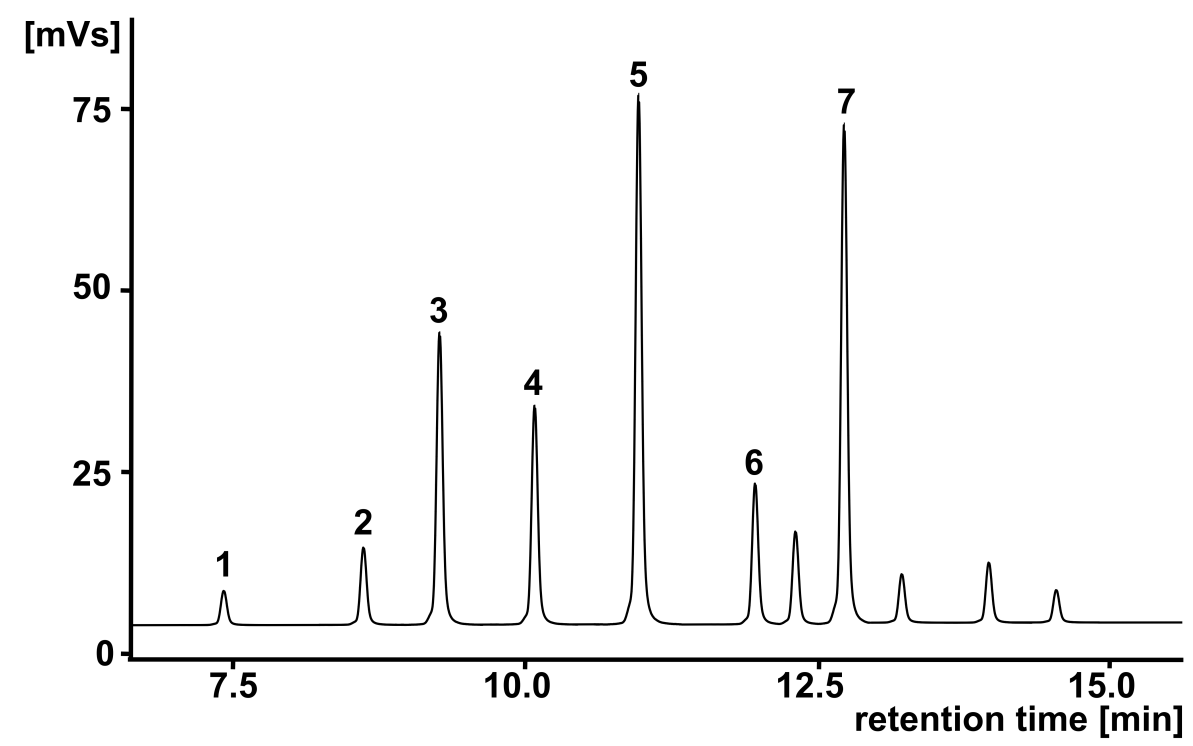

Fig. 4. Chromatogram of condensate a fresh compost pile sample [1 - ethanoic acid, $\mathbf{2}$ - propanoic acid, 3 - 2-methylopropanoic acid, 4 - butanoic acid, 5 - 3-methylbutanoic acid, 6 - pentanoic acid, 7 - $25 \mathrm{mg} \mathrm{dm}^{-3}$ of 2-ethylbutanoic acid] 


\section{Conclusions}

Short-chain monocarboxylic acids when present in aqueous samples can be well separated applying the separation system composed of SUPEROX FA II (Bio-Rad) /polyethylene glycol/, deactivated capillary, Restek Rtx-1 /dimethyl polysiloxane/ and guard column.

If the samples have a very complex matrix with some interfering compounds the samples can be satisfactorily cleaned-up using a distillation based apparatus. Enrichment factors can be increased by special modification of sample matrix. The detection limits ranged from 0.59 to $3.9 \mu \mathrm{g} \mathrm{dm}^{-3}$ depending on acid. The procedure can also be applied to some solids as sewage sludge after mixing it with water. The procedure can successfully be applied to analyse water for the content of SCMAs.

\section{Acknowledgments}

This work was financially supported by the Polish Ministry of Science and Higher Education (grant N N523 230535). A. Banel was partially granted by Marshal Office of Pomorskie Province. The authors thank Małgorzata Langowska, a student preparing M.Sc. thesis, for some help in the experimental work.

\section{References}

[1] Cruwys JA, Dnsdale RM, Hawkes FR, Hawkes DL. J Chromatogr A. 2002;945:195-209.

[2] Peldszus S. Organic acids. Chromatographic analysis of the environment, Nollet LML editor. Boca Raton, USA: CRC/Taylor \& Francis; 2006.

[3] Bozkurt S, Moreno L, Neretnieks I, Sci Total Environ. 2000;250:101-121. DOI: 10.1016/S0048-9697(00)00370-3.

[4] Siedlecka EM, Kumirska J, Ossowski T, Glamowski P, Gołębiowski M, Gajdus J, Kaczyński Z, et al. Polish J Environ Stud. 2008;17:351-356.

[5] Sosnowski P, Klepacz-Smolka A, Kaczorek K, Ledakowicz S. Biores Technol. 2008;99:5731-5737. DOI: 10.1016/j.biortech.2007.10.019.

[6] Water and waste water. Special tests for sediments and in water from above sediment by method distillation in steam. 1975, Polish Committee for Standardization PN-75/C-04616.

[7] Feng L, Gu Y, Zheng X. Environ Sci Technol. 2009;43:4373-4380. DOI: 10.1021/es8037142.

[8] Jurado-Sanchez B, Ballesteros E, Gallego M. J Chromatogr A. 2010;1217:7440-7447. DOI: 10.1016/j.chroma.2010.09.075.

[9] Lou DW, Lee X, Pawliszyn J. J Chromatogr A. 2008;1201:228-234. DOI: 10.1016/j.chroma.2008.02.066.

[10] Senturk E, Ince M, Engin OG. J Hazard Mater. 2010;176:843-848. DOI: 10.1016/j.jhazmat.2009.11.113.

[11] Zhang P, Chen Y, Huang T, Zhou Q. Chem. Eng. J. 2009;148:348-353. DOI: 10.1016/j.cej.2008.09.007.

[12] Alkaya E, Kaptan S, Ozkan L, Uludag-Demirer S, Demirer GN. Chemosphere. 2009;77:1137-1142. DOI: 10.1016/j.chemosphere.2009.08.027.

[13] Banel A, Wasielewska M, Zygmunt B. Anal Bioanal Chem. 2011;399:3299-3303. DOI 10.1007/s00216010-4415-z.

[14] Feng L, Huang Y, Wang H. J Chromatogr Sci. 2008;46:577-584.

[15] Yuan Q, Baranowski M, Oleszkiewicz JA. Chemosphere. 2010;80:445-449. DOI: 10.1016/j.chemosphere.2010.04.026.

[16] Cermak SC, John AL, Evangelista RL. Ind Crop Prod. 2007;26:93-99. DOI: 10.1016/j.indcrop.2007.02.001.

[17] Zygmunt B, Banel A. Chemia Analityczna. 2009;54:339-348.

[18] Pan L, Adams M, Pawliszyn J. Anal Chem. 1995;67:4396-4403. DOI: 10.1021/ac00119a031.

[19] Pan L, Pawliszyn J. Anal Chem. 1997;69:169-205. DOI: 10.1021/ac9606362.

[20] Morin-Couallier E, Bleton J, Lameloise ML, Tchapla A. Anal Chim Acta. 2007;259-265. DOI: 10.1016/j.aca.2006.10.024. 
[21] Peng F, Sheng L, Liu B, Tong H, Liu S. J Chromatogr A. 2004;1040:1-17. DOI: 10.1016/j.chroma.2004.03.057.

[22] Jerković I, Kovacević D, Subarić D, Marijanović Z. Food Chem. 2010;119:813-822. DOI: 10.1016/j.foodchem.2009.07.024.

[23] Peters TL. Anal. Chem. 1980;52:211-213. DOI: 10.1021/ac50051a054.

[24] Banel A, Jakimska A, Wasielewska M, Wolska L, Zygmunt B. Anal Chim Acta. 2012;716:24-27. DOI: 10.1010/j.aca.2011.02.059

[25] Konieczka P, Namieśnik J. Metod Validation. In: Quality Assurance and Quality Control in the Analytical Chemical Laboratory - a Practical Approach. Lochmuller CH, editor. CRC/Taylor \& Francis: Boca Raton, USA; 2009; p. 131-216.

\title{
OZNACZANIE KRÓTKOŁAŃCUCHOWYCH KWASÓW MONOKARBOKSYLOWYCH W PRÓBKACH WODNYCH I STAŁYCH POCHODZĄCYCH Z OCZYSZCZALNI ŚCIEKÓW Z WYKORZYSTANIEM CHROMATOGRAFII GAZOWEJ POPRZEDZONEJ DESTYLACJA
}

\author{
Katedra Chemii Analitycznej, Wydział Chemiczny, Politechnika Gdańska
}

\begin{abstract}
Abstrakt: Krótkołańcuchowe kwasy monokarboksylowe (KKM) (C2-C5), powstające w procesie biodegradacji tlenowej większych cząsteczek organicznych, powinny często być monitorowane w celu optymalizacji biologicznego oczyszczania ścieków i zbadania procesów przekształcania odpadowej materii organicznej na metan itp. W przypadku oznaczania KKM w różnego rodzaju próbkach środowiskowych chromatografia gazowa (GC) wydaje się być metodą stosowaną $\mathrm{z}$ wyboru. Większość próbek wymaga oczyszczania przed ich wprowadzeniem do systemu chromatograficznego. W niniejszej pracy zastosowano specjalne urządzenie pozwalające na wzbogacenie i oczyszczenie kłopotliwych próbek środowiskowych przed analizą chromatograficzną. W celu optymalizacji rozdzielenia KKM w wodnym roztworze zastosowano specjalny układ dwóch kolumn kapilarnych o bardzo różnej polarności. Etap przygotowania próbki oraz parametry wzbogacania zostały zoptymalizowane. Opracowaną procedurę zastosowano do oznaczania KKM w próbkach wodnych o złożonej matrycy oraz stałych pochodzących z oczyszczalni ścieków.
\end{abstract}

Słowa kluczowe: krótkołańcuchowe kwasy monokarboksylowe, destylacja, chromatografia gazowa z detekcją płomieniowo-jonizacyjną, ścieki 